\title{
Staging the Truth
}

Psychoanalysis and Pragmatism

\section{Roberto Brigati}

\section{(2) OpenEdition \\ 1 Journals}

Electronic version

URL: http://journals.openedition.org/ejpap/381

DOI: 10.4000/ejpap.381

ISSN: 2036-4091

Publisher

Associazione Pragma

\section{Electronic reference}

Roberto Brigati, « Staging the Truth », European Journal of Pragmatism and American Philosophy [Online], VII-1 | 2015, Online since 07 July 2015, connection on 01 May 2019. URL : http://

journals.openedition.org/ejpap/381 ; DOI : 10.4000/ejpap.381

This text was automatically generated on 1 May 2019.

\section{(c) $(1)$}

Author retains copyright and grants the European Journal of Pragmatism and American Philosophy right of first publication with the work simultaneously licensed under a Creative Commons Attribution-

NonCommercial-NoDerivatives 4.0 International License. 


\title{
Staging the Truth
}

\author{
Psychoanalysis and Pragmatism
}

\author{
Roberto Brigati
}

\section{What is Truth in Psychoanalysis?}

1 Psychoanalysis has a special relation to its clinical practice. ${ }^{1}$ While claiming truth as a theory in its own right, it cannot help relying on its clinical effectiveness. This is not to say that the theory is true because, or insofar as it (clinically) works; rather, the theory is often evaluated in the light of the practice, and vice versa. It might appear that psychoanalysis, particularly as seen from a pragmatist standpoint, needs no more than clinical success: let the patient be healed, and truth will take care of itself, as Rorty might have put it. But hardly any Freudian today would subscribe to anything like this; and I surmise most pragmatists would not like Rorty's catch phrase to be turned into a cliché that downplays any reference to truth whatsoever. What I mean to show is, rather, that psychoanalysis is a distinctive illustration of the pragmatist concept that effective explanations are, in Dewey's words, "experimental," and adjust themselves to real processes while changing reality, and indeed by changing reality. ${ }^{2}$ Thus, while truth is definitely taken care of in psychoanalysis, it enjoys a peculiar status, being what one might call an emergent property of a relational process. But not just any relational process, even if it "works," will produce truth. This is what I hope to show by way of, among other things, a comparison of Sigmund Freud's and Pierre Janet's clinical approaches.

2 Some initial objections will be addressed here. First, according to popular view, psychoanalysis is supposed to confirm itself through its effectiveness. Yet at the same time, psychoanalytic theory is often criticized in view of its purported lack of clinical effectiveness, which confirms the privileged relationship hinted at above. Second, Freud himself, up to a certain not so early date, was inclined to resort to such legitimation. His reworking of this view may be regarded as a lengthy, tentative process, whose beginnings lie in his rejection of the cathartic method, and was not completed until his last great technical writings of the 1930s, if ever. 
3 Why, then, should a pragmatist reading of psychoanalysis look for more than effectiveness? In a way, effectiveness is, of course, crucial to any applied science. Science is pragmatist, albeit unknowingly, insofar as it claims truth and usefulness: for "it is a strict truism that no one would care about any exclusively theoretical uncertainty or certainty" (Dewey LW 4: 31). This holds a fortiori of medicine, regarded as a practical enterprise that does not make much of the distinction between theoretical truth and the fulfillment of clinical needs.

4 Biomedicine, however, is in a position to validate its conclusions by the standard means that are typical of empirical science: most notably by experimental methods. These are, vice versa, only hazardously available to psychoanalysis, and on a very limited basis, in view of the near-impossibility of double-blindly checking observational results versus placebo, and indeed of arranging any control group for experiments. Confidentiality issues, length of treatment, and high fees do the rest. In short, the informational standards that could be acceptable for nomological-deductive science are scarcely obtainable in psychoanalysis. $^{3}$ Some biologically-oriented psychiatrists think psychoanalysis could catch up with standards of scientific testing "by developing a closer relationship with biology in general and with cognitive neuroscience in particular"4, but such views do not go unchallenged in the trade. Freud was aware of the poor standing of experimentation in analysis, but tended to think clinical observation alone would suffice (Freud 1932: 22). This was actually an old Comtian view, later taken up in turn by Théodule Ribot (Babini 1990: 79), but it hardly fulfills modern scientific requirements for ideal establishment of truth.

5 Scientifically-minded critics have almost invariably seen the precarious, incomplete or absent application of an experimental method to psychoanalysis as an inadequacy on its part. Psychoanalysis would thus be incapable both of validating its claims and of proving the substantiality of its ontology. This critique obviously assumes that psychoanalysis is both willing to and in need of validating itself along experimental lines. This is undoubtedly encouraged by the fact that Freud was scientifically-minded (while of course seeing no inadequacy in his approach). The reaction of quite a number of psychoanalysts and Freudian theorists to scientific critique has been either: to correct Freud's epistemology, turning to non-standard views of it (sometimes more or less appropriately tagged as "pragmatic" ones); or to emphasize some non-standard ontological view of the mind, for instance by interpreting the constituents of Freud's "first topography" as "constructs," i.e. not things whose existence must be proven. ${ }^{5}$

6 To those who insist on experimentation, but are willing to be charitable, psychoanalytic theory may, at best, seem to be confined to a supposedly more primitive stage of scientific development. This stage is described by the Platonic imperative of saving the phenomena, i.e. concocting some explanation which would account for what is observed, including the patients' recovery. In a Platonic mindset, competing explanations, if ever possible, are first and foremost selected on criteria of "elegance." Something similar might also be attributed to psychoanalysis, in view of Freud's literary talent and the fascinating character of psychoanalytical narratives. ${ }^{6}$ It would seem, then, that psychoanalytic theory is ancillary to its practice, perhaps with some literary embellishments on top of it. This over-pragmatization of psychoanalysis would put the power of healing at the centre, by whatever means it is achieved; some fancy explanation will later be developed through theorizing. This is only slightly different from the Rortyan-like slogan I evoked earlier, since here someone (the storytelling analyst) 
actually does take care of the truth. But again, not just any manner of taking care of the truth will do. The distinctively psychoanalytic way may involve narrative, but not for the sake of mere elegance.

7 A second superficially "pragmatist" trait of psychoanalysis is that it is widely believed to use the patient's assent as a proof of its validity. Again, Freud was not alien to this way of thinking. In his words:

After all, [the patient's] conflicts will only be successfully solved and his resistances overcome if the anticipatory ideas he is given tally with what is real in him. (Freud 1916: 452)

8 This is what Adolf Grünbaum (1984: 135 and passim) famously termed "the Tally Argument." He was thus trying to call Freud's bluff. The analysts, Grünbaum implied, do not know what is real or what the means by which they actually, if at all, achieve success are. They merely reassure themselves and their audience, hoping things will turn out well in the end. Here again, cliché pragmatism might be comfortable with this reassurance, as far as the client is satisfied and the goal achieved. Surely, though, this kind of pragmatism, as well as Grünbaum's criticisms, leaves something out. Admittedly, explication (the mandatory mission of any theory) merges here with cure (the necessary goal of any clinical practice). And of course the patient's resistances need to be overcome. But why then does it work only sometimes? Either ideas do tally with what is real, and the scientifically-minded Freud was right, or there must be more to clinical success than just tallying.

One way to disentangle the matter is to suggest that psychoanalysis does not function because of its truth but rather by means of it. Its putative truth encompasses efficacy, not so much because it is recognized as true by the analysand, but because it is appropriated by him or her in a special way. "Tallying" is what "ideas" do, but even tallying ideas are of no use to the analysand, unless they are couched in a practical construction that I intend to call the dramaturgical staging of the truth. Psychoanalysis is not an idealistic undertaking, and its constructions, far from just tallying the analysand's inner realities, interlace in a complex manner with the analysand's history, search for clinical help, and willingness to assent. Its goal is to produce changes in the analysand. What I want to show is that such interlacing is not adequately described either in Grünbaum's hypotheticaldeductive scientific vocabulary, or in the militant language of medicine that Janet was somehow fond of.

One perspective which merits consideration before moving on is the one according to which psychoanalysis is capable of experimental test after all, despite passing them or not. I will use one example among the many, partly because it is a self-styled "pragmatic" thesis. It is Charles Hanly's suggestion that, in psychoanalysis, the prediction of remittal (or indeed even of the worsening of symptoms, relapse or backlash) might be the only form of theoretical hypothesis that could be empirically verified along hypotheticaldeductive lines. ${ }^{7}$ Owen Renik (2004: 1062) had expressed much the same point:

In science, always, the true hypothesis is the one that works best - the one that makes the most successful predictions under the greatest number of conditions.

11 This proposal, one should note, differs both from the successful-cure and the Tally arguments, since what counts here as a verification of theories is neither clinical success nor acceptance by patients, but the prediction of "facts," i.e. subsequent observational findings (successful or not). 
While this suggestion may be helpful in getting closer to understanding what is "pragmatic" in psychoanalysis, it is far from settling the issue. Broadly speaking, of course, if a theory predicts facts that (other things being equal) do not hold, not even "in the long run," it can hardly be true. In analysis, however, the nature of relief and healing, as well as their evaluation, are open to question - and possibly for the best. Will a reduction of symptoms suffice? To what extent? And, more important, who is to judge this? Again, the client's satisfaction seems to come to the fore. But every client is a person who experiences pressures from social agencies, so how far is that satisfaction really the client's? Is it a matter of straightening people out, so that they can re-assume their place in production and consumption, social interaction, family life, sports, fun industry? One should bear in mind that this "hygienic" function has often been blamed on psychoanalysis, particularly on the US branch. Indeed, this was seen as a deplorable consequence of "American pragmatism," which was charged with acquiescence to the social status quo and market laws. ${ }^{8}$

Moreover, prediction can be meaningful only if one constantly knows which parameters are being varied from one experimental situation to another. Thus, if we were to look for an evidence-based psychoanalysis, techniques and approaches would need to be far more standardized than they are. Seeing as analysis is so dependent on personal characteristics, it is not even clear that such uniformity is desirable.

\section{The Pragmatic Theatre of Transference}

14 In this consideration of ways for conceptualizing truth in psychoanalysis despite the lack of experimentation, I would now like to draw attention to two interesting and considerably intertwined reactions to the crisis of psychoanalytic epistemology. ${ }^{9}$ One has been the narratology-cum-hermeneutics turn, according to which psychoanalysis is not actually a natural science but rather a practice based on interpretive discourse and (self)narration, so that the question of truth becomes comparatively marginal. ${ }^{10}$ The other one attempts to invoke a "pragmatic theory of truth,"11 insisting that what is going on in psychoanalysis are actions and practices, and that its truth more or less coincides with the usefulness of these practices. It is not always clear whether such claims appeal to the success of a treatment as evidence for the truth of the interpretations provided by the analyst during that treatment, or to the general effectiveness of psychoanalysis as a proof of its entire ontology of mind.

15 Now, the insistence on both narration and action is, in its gist, correct, and may be fruitfully developed..$^{12}$ However, one should be careful not to excessively narrow the interactional and communicational forms psychoanalysis may take, its "literary genres," as it were. Ricœur, for instance, holds that "the object" of psychoanalysis consists of " 'comptes rendus' (reports)." ${ }^{13}$ This obscures the fact that the central event of an analysis, i.e. transference, is not the telling of a story but a highly articulated dramaturgic relationship: it's theatre, not a novel. Consider, in this regard, Freud's crucial use of the word Agieren, "acting out," in the 1914 Remembering, Repeating and Working Through (this idea had already been presented in the 1901 Dora case, and can be found throughout his papers on technique). By and large, a certain under-evaluation of transference is characteristic of quite a few philosophical interpretations of Freud, including Wittgenstein's and Habermas.' Within the analytic relationship, action is not mere discourse nor plain intentional action. It follows a script, so to speak, and the aim of 
treatment is to bring this script more and more under the control of the subject (i.e. her/ his Ego). Transference is the means by which the script can be brought to consciousness, understood and re-written.

The neglect of transference, and of its theatrical component, is likely a key reason why an excessive weight has been attributed to the issue of proof. And in turn, an overestimation of the importance of proof is but the reverse side of misunderstanding what effectiveness and healing really are. Now pragmatism may be particularly exposed to these two strictly connected errors, precisely because of aspects which, in fact, seem to draw it close to psychoanalysis. Pragmatism's anti-intellectualism certainly favours proof-by-deed over theoretical proof. This, however, is one of the reasons why I regard psychoanalysis as a unique occasion with which to reflect on what really are the "effectiveness" and the "making of a difference" that pragmatism invokes in its construal of meaning and knowledge.

The chief temptation to avoid is to confuse therapeutic success with either (1) the relation of facts and propositions in the correspondence theory of truth; or (2) the hypothetical-deductive model of scientific knowledge.

18 As to (1), the effectiveness of treatment is not a truth-maker of theoretical statements, at least not in the sense of being a one-to-one function relating "interpretations" proposed by the therapist to "things" or events in the mind of the client; nor, as regards (2), can therapeutic success be assumed as pointing to, or standing proxy for, the explanatory correctness of the relevant theoretical constructions.

19 Now, the view that success is not proof of either truth or explanatory power might appear as a hindrance for any pragmatist reading of psychoanalytical treatments, if pragmatism's dictum "true is what works" is interpreted in its more facile sense. Still, pragmatist readings of psychoanalysis and psychodynamically-oriented therapy have been attempted several times. ${ }^{14}$ David Brendel has recently defined the pragmatic stance on psychiatry in the following terms:

[...] psychiatric explanations ought to be practical [...] and thus are valid only insofar as they promote beneficial real-world results for individuals who seek mental health care. $(2006: 37)^{15}$

20 Pragmatic inspiration, in any case, is not a last-minute discovery for psychoanalysis. While taking little interest in pragmatism, Freud himself occasionally drew upon its resources, and approvingly mentioned some pragmatist-related authors:

The value of a "fiction" of this kind (as the philosopher Vaihinger would call it)

depends on how much one can achieve with its help. (Freud 1926: 194) ${ }^{16}$

21 Peter Illes (1996) has interestingly noted that whenever Freud addresses a psychoanalytic audience - thus being free from defensive worries - the conception of truth he implicitly appeals to is a "pragmatic" one. Quite revealing avowals can be found in other classic texts as well:

The extraordinary successes of Freudian interpretations suggest not only not to abandon such fruitful methods of work, but even to extend their application to further areas, taking its success, in a pragmatistic vein [im pragmatistischen Sinne], as an evidence of its correctness. (Ferenczi 1922: 127)

22 Yet, as we mentioned before, success can be murky, both for analysis and for pragmatism - because success is hard to measure, hard to explain, and, unless we are comfortable with the adaptive-hygienic model of success, is not self-justifying. 


\section{Manipulation and The Pragmatics of Healing}

Before we bring therapeutic success into the picture, there are initial questions to be asked. Success in what? For whom? Or, to put it in pragmatist jargon, what is the difference analysis makes? What exactly is this practice after, and by what means? The meaningfulness of any pragmatist programme on psychoanalysis depends, in a crucial way, on the goal the treatment is intended to achieve - on what one is willing to count as healing. The goal of analysis cannot be simply the achievement of "happiness," if only because according to Freud this is strictly speaking unattainable by humans, since the pleasure principle itself is at odds with reality. ${ }^{17}$ of course pragmatism requires "beneficial results" (Brendel), but this is a notion whose depth may vary enormously, and at each variation the concept of evidence and the methods of verification have to be rethought accordingly. Instead of pursuing a definitional course of reasoning, I will now try to shed light on the matter by comparing psychoanalysis to a different therapeutic method, developed by one of Freud's great precursors and one-time rivals, the French neurologist and physician Pierre Janet (1859-1947). Starting in the last decades of the 19th century, Janet had already developed a notion of the unconscious and a view of abnormal psychic life as characterized by conflicts involving traumatic memories of the past (although usually not of a sexual nature, nor very remote in time).

Indeed, Janet seems to qualify much better for being a "pragmatist" therapist than Freud. Let us summarize his main assets.

(1) First, his practical/particular rather than theoretical/universal preoccupation, which made him attentive to "observations individuelles":

I am convinced that only by studying natural experiences, rather than by theories and quantitative measuring, one will get a better understanding of our intelligence and our actions. [...] To someone who, like me, admits to not wholly understanding general theories of fixed ideas, each ill person is interesting in himself. Janet 1898: I, 1-2)

(2) His explicit reference to Henri Bergson and his "pragmatism." A well-known admirer of William James, Bergson had insisted, particularly in Matière et mémoire, on human action conceived of as something which is set in present time and purports to have effects in the future. In defending Bergson from the ensuing charges of "pragmatism," Janet straightforwardly maintained that, within the domain of psychology, pragmatism is a necessity. ${ }^{18}$ At the same time, he diverged from Bergson regarding the status of memory (which we will find crucial to his treatment of psychic disturbances of traumatic origin). His view was actually strikingly akin to what one might expect from a social interactionist in a Meadian vein. Memories are not things or inscriptions immediately acquired through the senses and stacked away for future usage, but the result of an individual's being placed in a relational network. "A man alone has no memory, nor needs one," wrote Janet, and "memory is a social function in the first place." ${ }^{19}$

27 (3) His inclination, in theoretical psychology, toward Baldwin's functionalism and James' empiricism (see Ellenberger 1970/1994: 400-406). Behaviourism was also among his inspirations, but he reinterpreted it as "behaviorisme élargi," which implied a focus on complex, directed action, involving mental operations, whether conscious or "automatic." This is what he also called conduite (rather than comportement, too elementary a category to be useful, according to him). ${ }^{20}$ 
28 (4) His repeatedly affirmed evolutionism, although this was probably less inspired by Darwin than by the French tradition of historical and anthropological evolutionary thought (Comte, Lévy-Bruhl).

(5) Above all, his decidedly medical orientation, i.e. his commitment to effective results rather than idle speculation (as he largely considered Freud's work to be).

What is interesting, from our point of view, is that some of Janet's most "pragmatist" features are precisely those that make his therapeutic methods dubious, at the very least. In this light, the comparison of Janet and Freud questions our view of pragmatism itself.

31 Janet's pragmatic orientation seems to bring him to what one might call an absolutization of healing. He was in no way loath to theoretical amendments, and indeed some of his constructs underwent considerable change. For instance, his concept of dissociation was groundbreaking, and had a major influence on Breuer and Freud (Thoret et al. 1999). ${ }^{21}$ However, at least according to Hacking (1998: 212, n. 61), there are hints that by 1937 "Janet had long [...] dumped dissociation as a valuable concept." On the other hand, Janet repeatedly defended his therapeutic methods, even once the wave of hypnotic cure was over and his methods were questioned both from psychoanalytic and other quarters (see e.g. Janet 1923). Despite his highly sophisticated view of the human mind, and despite his conceptual richness, displayed in a huge body of writings throughout an unusually long career, his therapeutic approach was straightforward and remained unvaried to the end.

The routine was comparatively simple. Having caught a (usually brief) glimpse of what the patient's psychic goings-on were, he used hypnosis to tackle them. Hypnosis had also been the chief methodological resource of Jean-Martin Charcot, whom Freud recognized as his master, and of course Breuer and Freud applied it extensively until 1895. But Breuer and Freud used it as a heuristic tool, not as a tampering one. They tried (at least until Freud abandoned this line altogether) to bring out deep memories, not to alter or create them. Which Janet did attempt, however, persuaded as he was that many an illness was due to idées fixes, mental representations which could be mended or even forged.

So he would, for instance, blur, through hypnotic suggestion, a given haunting visual image:

There was, particularly, a terrifying hallucination, a gloomy picture which Marcelle was haunted by. I managed to transform it so well, by mixing it up with other hallucinations, that the patient eventually couldn't recognize it any more, so that I could remove it without effort. (Janet 1898: I, 58)

Let us take one of his poster children, Justine, who, "at seventeen, was strongly struck by seeing two corpses of people dead from cholera," and now, at forty, undergoes frequent "cholériformes" hysterical crises. When in a state of "somnambulisme," i.e. under hypnosis, she is able to detail the visions that visit her.

There were first of all visual images: two corpses, one of which came to the fore, "a poor old man, naked, greenish-bluish"; then smell sensations, a stench of putrefaction; then auditive images, "death bells, cries of 'cholera, cholera'." (Janet 1898: I,161)

Now, as opposed to Breuer and Freud, whose methods he regarded as too weak, Janet did not confine himself to eliciting memories, but took control over them:

[...] we think it possible, in some cases, to take control over automatic phenomena

[...] So I tried to transform the aspect of the corpses and above all I spent various sittings to dress them. A first hallucinatory dress, then a second, were successful enough: in the end, the main corpse appeared in the uniform of a Chinese general 
whom Justine had seen at the Expo. Success was complete when I managed to make him stand up and walk: he thus was no longer threatening, and an element of most cheerful comedy came to be added to the attack. (Janet 1898: I, 163, 164) and can be subject to rearranging as well (Thoret et al. 1999: 756). This was coupled with a causal theory, the belief that neuroses follow from a sort of mental weakness (conceived of in energetic terms), a disability determined by some hereditary factor ("fatal biological handicap," wrote Zilboorg in his classic history of psychiatry). ${ }^{26}$ There was no hope of, and no point in, establishing a relationship with someone affected by degenerative processes (dégénérescence). He therefore reacted harshly against the "medical 
moralization" (Janet 1923: 41) of those who viewed therapy as verging on education or mind-cultivation. This does not mean that his method was not about correcting mental mistakes; ${ }^{27}$ only, this was supposedly achieved by planting correct and rational ideas in the patient's mind in lieu of the false ones. In his opinion,

[...] hypnosis should be considered no different from medical technologies such as drug therapy or surgery, the efficacy of which did not depend on the patient's insight or awareness. ${ }^{28}$

This causal ontology mainly applied to the pathological condition he termed psychasthénie, characterized by "considerable disorders of will and attention, difficulty of mental functioning, diminishing short-time memory" (Janet 1898: I, 98). But some hereditary predisposition was also to be presumed in the case of hysteria, the other major group of disorders Janet acknowledged, even if in this case a traumatic event was the most common catalyzing fact.

It has to be noted that such an objective, bodily aetiology of hysteria was part of a sympathetic, if patronizing, gesture toward the patients.

Many French physicians were loathe to admit hysteria to the status of a legitimate disease. [...] In the contemptuous language of [Salpêtrière physician] Jules Falret, the women who purported to suffer from hysteria were "veritable actresses; they do not know a greater pleasure than to deceive... all those with whom they come in touch." (Scull 2009: 107)

Through his authority, Charcot had achieved a lot in undermining this disparaging view, insisting on neurological causes. However, the heavily showy nature of his demonstrations did not contribute to dissolving the aura of fakery surrounding the illness (Scull 2009: ch. 6). In any case, it continued to be considered a disease based on self-deception, and its symptoms were somehow regarded as superficial. A specific therapeutic attitude followed from this view, a sort of immunity or free-hand for devising therapeutic methods. Hippolyte Bernheim (1840-1919), one of the best experimenters in suggestion and hypnosis, was probably the first to use the induction of pseudomemories in patients (Pintar \& Lynn 2008: 156). This, it seems to me, was justified by the belittling of the obsessions involved, seen as a sort of self-delusive, epiphenomenal ideas, superfluous representations which were akin to superstition. This is why Bernheim did not bother with detecting forgery (Janet 1923: 22), about which Charcot was so worried. Every instance of hysteria was simply more or less a forgery, however unwitting.

Seen in this light, therapy would have consisted in revealing to patients the self-inflicted nature of their suffering, and in dissolving their delusions by showing their insubstantiality. Bernheim himself occasionally remarked that the therapy of hysteria was to be more a "de-suggestion" than a suggestion. ${ }^{29}$ However, enlightenment can be paradoxical - the potential enlighteners were transformed into manipulators, conjuring up chimeras for the sake of "de-suggesting" patients.

Janet's approach was different only in that it was even more muscular, based on his ontological and aetiological convictions. He firmly believed neurotic symptoms to be well-founded, i.e. not only not forged, but also organically-based - yet he tried, by whatever means he could, to convince the patient they were unreal. He even realized that suggestion is at best a beginning, the kickoff of a cure. Sometimes he appears to be aware that it should be possible to move to further stages of personal growth, elicit more productions, deeper insights and a more complex conduct on part of the patients:

I forbade Marguerite to have further crises, and that was that. Yet, her sensitivity, her memory, her movements, her whole character and conduct had been modified. 
Often I could make her sleep without any suggestive command, and still there ensued a period of [good] influence. (Janet $1898:$ I, 444) is quite prepared to admit that the cure will always be palliative and short-to-mediumlived, at least until we will learn how to directly tackle the organic sources. That is why suggestive techniques are morally justified, in his eyes, provided they work (or work better than ignoring the symptoms). The justification for this is plain Hippocratic ethics, paternalistically viewed: "a sick person is sick, and our noblest duty is to cure him the best we can, that's all" (Janet 1923: 154). Thus, patients are "weak," and ought to be helped accordingly, even by shrewd means, for their own good. Moreover, Janet artfully denies any collateral damage of his treatment, while providing preemptive justification for it, in terms of the dual effect of any pharmakon whatsoever:

[...] a medicine can really be effective only if it can be dangerous, and it is difficult to conceive a therapy which is simultaneously effective and always harmless. (Janet 1923: 153)

Alternatively, and ironically enough, he sometimes implies that deceiving neurotics is a way of treating them as adult beings, avoiding the purported pitfalls of both Freudian psychoanalysis and moral catechism, which tend to

consider the neuropathic and alienated as lazy, ignorant pupils, or as penitents, to

be taught fashionable morals and truths. (Janet 1923: 154)

People want to be cured and go back to their business, and they are entitled to get the best cure they can afford. Thus, it is really Janet's therapy that aims at pursuing social adaptation - precisely the role attributed, right or wrong, to "American psychoanalysis." If this is pragmatism, it is admittedly a rather crude variety, one which peers through the boundaries of the patient's subjective life reaching for the "real" locus of disease - the nervous system - while discarding the relevance of not only sexual drives, but even social relationships and familiar conflicts. Janet was not after real personal growth. His refusal to teach lessons is, eo ipso, the refusal to share knowledge. One might say he took patients' statements at face value. When patients described their de-personalization, their phenomenological emptiness, when they said things such as: "I am nothing but a machine and it takes me some painful effort to be someone" (Janet 1909: 141), these words were taken as indexes (in Peirce's vocabulary), not as bearers of meaning. That is to say, not as expressions of an inner life, but as effects of an inner degeneration. Janet definitely did not belong to what Ricœur labelled the maitres du soupçon.

We cannot further analyze this matter here. The general lesson, I think, is that the combination of pragmatism and paternalism can be dangerous enough. The specific lesson might consist in a better understanding of psychoanalysis and its pragmatic orientation.

51 Indeed, Freud shared a version of the organic theory of psycho-pathogenesis, but he did not see (contrary to Breuer) hysterical states as being caused by a weakening of psychic functioning. ${ }^{30}$ Thus, he placed the organic cause theory in brackets and never paid it more than lip service. Such causes, I surmise, were meaningless to him. Janet (and possibly Charcot before him) had rejected the implication of moral failure hidden in the notion of "weakness." However, Freud rejected the entire idea of there being inexpressive, irrelevant aspects of psychic life, merely characterized by their powerlessness; dead parts of psychic life, as it were. Sure, there were organic facts involved, but Freud decided to treat them as a black box, as efficient but inscrutable causes. His method consisted of 
attributing meaning to subjective acts, i.e. precisely considering them subjective and not merely objective.

This, then, is the difference psychoanalytic treatment makes. Its goal is not discovering the (physical) thing which materially generates the effect - this could be a task for a more developed neurology, that is not in sight. Instead, it intends to find what makes a difference to patients and helping them to master it. ${ }^{31}$ So analysands have their own tasks to carry out.

The treatment is made up of two parts - what the physician infers and tells the patient, and the patient's working-over of what he has heard. The mechanism of our assistance is easy to understand: we give the patient the conscious anticipatory idea and he then finds the repressed unconscious idea in himself on the basis of its similarity to the anticipatory one. This is the intellectual help which makes it easier for him to overcome the resistances between conscious and unconscious. [...] And further, in speaking to you I need not rebut the objection that the evidential value in support of the correctness of our hypotheses is obscured in our treatment as we practise it to-day. (Freud 1910a: 141-2)

Here Freud is referring to the fact that practice has become less "inexorable and exhausting" - more co-constructed as we would now say - and an important part of the work of overcoming resistances is allocated to the analysand. And he further specifies:

[...] you will not forget that this evidence is to be found elsewhere, and that a therapeutic procedure cannot be carried out in the same way as a theoretical investigation. (Freud 1910a: 141-2)

This is not to deny that psychoanalysis had its share of suggestion and even paternalism. In The Dynamics of Transference Freud wrote:

To this extent we readily admit that the results of psycho-analysis rest upon suggestion; by suggestion, however, we must understand [...] the influencing of a person by means of the transference phenomena which are possible in his case. We take care of the patient's final independence by employing suggestion in order to get him to accomplish a piece of psychical work which has as its necessary result a permanent improvement in his psychical situation. (Freud 1912: 105-6)

No real change, in any region of life, is possible without suggestion. The neurotic does not suffer "from a sort of ignorance," which could be cured "by giving him information" (Freud 1910b). This is a belief Freud shared with Janet, as we have seen, but Freud's central insight on suggestion is that it functions both ways. No analyst could cure any person unless $\mathrm{s} /$ he takes interest in them.

This is not the place to address the technical problems surrounding counter-transference and its handling, which has come to be both one of analysis' central assets and one of its most debated issues. But my conjecture, which I will leave open, is that resolving this issue would be helpful for managing a subtle problem in the epistemology of pragmatism. In a nutshell, a void is left by renouncing the "Search for the Immutable" (the title of ch. 2 of Dewey's Quest for Certainty, LW 4: $21 \mathrm{ff}$.). If there is no "invariant" (LW 4: 16), how do we formulate hypotheses to submit to the test of practical relevance? How do we select the ideas which must be put to work? By trial and error? With all due respect to the freedom of postulates that pragmatism rightly invokes, this would be rather impractical for psychotherapy. If part of Dewey's answer is reflective knowledge, then transference may contribute to explaining what this might mean. The analyst certainly does something to her/his object of knowledge, thus inducing changes in it, as pragmatic epistemology mandates. But these objects are subjects, which means that: (i) they respond to symbolic, as well as physical, stimuli; (ii) they respond autonomously, i.e. not entirely predictably; 
(iii) they respond in such a way as to involve the "observer" in a relationship, which is admittedly non-symmetrical, ${ }^{32}$ but is, in any case, a subject-to-subject relation. Thus, the analysands do something to the analyst as well, who may learn from the changes the relationship induces in her/himself. The very way in which a patient may affect the analyst could turn into a source of inspiration for the latter.

We cannot pursue this line of thought further here, so we turn back to the issue of proof in psychoanalysis.

\section{The Question of Proof Revisited}

Two of pragmatism's most important features are particularly relevant in connection to the cluster of problems posed by the notions of proof, truth, and success in therapy. They are:

1. its being future-oriented, i.e. its attention to what will happen rather than to what has happened (see Bergson 1911/1950: 246 about James);

2. what has been called its "holism" (Goodman 2004: 14), i.e. the idea that verification involves a whole practice or conduct, rather than a single fact constituting evidence for a single proposition.

I think it should be clear by now that both features have their counterparts in psychoanalytic theory and practice. In passing, we may note that it has been argued that issue (1) may belie the relationship between pragmatism and psychoanalysis. Pragmatists might come to regard analysis as a "mourning science," a sort of depressive-passive look into the past, which offers no clues as to how to develop practical tools for life, ${ }^{33}$ Thus, Vincent Colapietro (2004: 178) writes:

From a pragmatic perspective, psychoanalysis can seem to foster a morbid fixation on an unrecoverable past. ${ }^{34}$

But psychoanalysis, being, after all, a healing practice, cannot but be devoted to bettering the patients' future lives. The past is featured, within this practice, only because there are, counter-intuitively, things one may do about one's past, notably attempting to find ways of living with it. The reenacting/dramaturgic character of both the interpretations and the transference relationship is but a means for this.

Thus, psychoanalysis does not use the past in a "contemplative" manner, i.e. as a source of historic episodes (or fantasies) which function as truth-makers of conjectural propositions, on a correspondence theory basis. Therapy, we saw, does not amount to informing analysands of some truth about themselves. Despite the fact that analysis delves into the patients' past in the attempt to bring out their unconscious conflicts, such "delving into" is not the cure itself, contrary to the old cathartic theory. "Chimneysweeping" (as it was aptly described by Anna O.) is but one stage of the treatment. The very fact that the "cure" is ultimately performed only within, and thanks to, transference prevents such a "spectator-theory" (in Dewey's phrase) from being applied to past psychic conflicts. At the same time, I think we have seen evidence enough of the importance of the analysand's becoming active in the analytical process. Of course, this does not wipe out the role of suggestion; but, if my hypothesis is valid, the same holds for every deep personal transformation and possibly for every human choice. 
Where are we left now with the "truth" of psychoanalysis? Does effectiveness "prove" it? And is confirmation by the patient about the analyst's interpretation required for effectiveness?

There are some telling passages in the Wolf Man story (one of the most debated and harshly criticized among Freud's cases). This case is the occasion for Freud's best known reconstruction of a primal scene, and at the same time, for his pointing out that confirmation is not, and indeed cannot be, the extraction of an occurrence from the patient's mind. Primal scenes cannot be evoked as recollections in the patient's consciousness: "they are the products of construction" (Freud 1918 [1914]: 51). Nevertheless, they can be negotiated as part of what is agreed upon in the treatment. Thus, the Wolf Man

[...] thought that the posture of the wolf in this picture might have reminded him of that of his father during the constructed primal scene. (Freud 1918 [1914]: 29)

Strictly speaking, we might say, the unconscious never comes to consciousness, even if analysis intends to be a device for achieving exactly this - for replacing Es with Ich, as the Freudian saying goes. Such a formulation does not mean that Es is a sort of dormant Ich, suddenly awakened, or that unconscious contents are simply non-conscious ones waiting to come to the fore.$^{35}$ Rather, replacing Es with Ich means giving the subject more control of its own life, which can be seen in the production of new, interesting, vital material, including new dreams, new images, and new purported recollections. For sure, during a treatment there appear

[...] spontaneous recollections from [...] childhood, for the appearance of which [...] the physician feels himself entirely blameless, since he has not made any attempt at a construction which could have put any material of the sort into the patient's head (Janet may have been the implicit target here), yet "[i]t does not necessarily follow that these previously unconscious recollections are always true." (Freud 1918 [1914]: 51)

65 The analyst's interpretations may elicit an Aha!-Erlebnis (a phrase introduced by psychologist Karl Bühler), but this need not have the phenomenological quality of a proper recollection. Nevertheless, since the genuineness of recollection is not what breaks down resistances, the production of interpretations is far from being idle. Freud (still in the Wolf Man case) emphasizes that the story told by the analyst can nonetheless have a considerable impact on the analysand's reflective thinking, and come to be established as a strong belief and guidance. Hence it can, in pragmatic terms, become something to act upon in future life. Therapy may be said to consist in making the patient strong enough to endure this.

There is, further, an even more interesting passage in this case-history: Freud's cautionary remark, addressed to psychoanalysts, against trying to get information about past facts from the patient's family. This, Freud argues, may break the analytic alliance and reveal the doctor as a suspicious agent, looking for confirmations of the analysand's words. This shows how far psychoanalysis is from being an art of soupçon in a standard, correspondence-theoretical sense. Clearly the analysand's statements are not to be taken at face value, but this does not this mean one is only interested in their "realness," in the sense of historical truth. Strictly speaking, the only relevant reality in analysis is psychic reality. Thus, the question to ask, rather, is "Is s/he free in telling this, or hampered by something?." We should remember that the fundamental rule of analysis is not the commitment to tell "the truth," but to tell loosely, freely; to which the analyst will 
respond with the well-known gleichschwebende Aufmerksamkeit, evenly suspended attention. The ethical concern which backs such a relationship is a promise to speak one's mind; of parrhesia and straightforwardness - not of objectivity.

The therapeutic theatre and its pragmatic "effectiveness," then, is a more complicated matter than one thought at the outset. For sure, it has to do with truth, but it does not "prove" truth; rather, it is a matter of relational honesty, personal authenticity, meaningfulness and expansion of one's inner life. Similarly, its effectiveness has to do with winning the analysand's agreement, but that agreement concerns the whole story, not just single interpretations. Again, listening, in a qualified way, to material produced by the patients is a major part of psychoanalytic method; yet, this method is not to be reduced either to discovering/reporting "what happened" (i.e. the History, in the old von Ranke's dictum) or to producing/narrating stories. What is at stake is rather the patient's capability to tell her/his story and do something with it. No matter how much such story is influenced by the analyst's constructions, it will become a tool in the analysand's hands. ${ }^{36}$

\section{BIBLIOGRAPHY}

BABINI V. P., (1990), La vita come invenzione. Motivi bergsoniani in psichiatria, Bologna, Il Mulino.

BERGSON H., (1911), "Sur le pragmatisme de W. James," Préface à W. James, Le pragmatisme (French transl.). Quoted from the re-edition in BERGSON H., La pensée et le mouvant, Paris, Alcan, 1950.

BRENDEL D., (2003), "Reductionism, Eclecticism, and Pragmatism in Psychiatry: The Dialectic of Clinical Explanation," The Journal of Medicine and Philosophy, 28, 5, 563-80.

BRENDEl D., (2006), Healing Psychiatry. Bridging the Science/Humanism Divide, Cambridge (MA), MIT Press.

BRIGATI R., (2001), Le ragioni e le cause. Wittgenstein e la filosofia della psicoanalisi, Macerata, Quodlibet.

BRIGATI R., (2003), "Figure della verità in filosofia e in psicoanalisi," Filosofia e Teologia, 17, 1, 46-53.

BÜHLER K.E. \& G. HEIM, (2001), “Introduction générale à la psychopathologie et à la psychothérapie de Pierre Janet," Annales médico-psychologiques 159, 261-72.

COLAPIETRo V., (2004), “The Question of Voice and the Limits of Pragmatism: Emerson, Dewey, and Cavell," Metaphilosophy, 35, 1/2.

DEWEY J., MW, The Middle Works of J. Dewey, 1899-1924, ed. by J.A. Boydston, Southern Illinois University Press, Carbondale and Edwardsville, 1976-1983.

DEWEY J., LW, The Later Works of J. Dewey, 1925-1953, LW, ed. by J.A. Boydston, Southern Illinois University Press, Carbondale and Edwardsville, 1981-1990.

DEWEY J., (1917), “The Need for a Recovery of Philosophy,” in MW 10.

DEWEY J., (1925), Experience and Nature, in LW 1. 
DEWEY J., (1922), Human Nature and Conduct, in MW 14.

DEWEY J., (1929), The Quest for Certainty, in LW 4.

Ellenberger H., (1970/1994), The Discovery of the Unconscious. The History and Evolution of Dynamic Psychiatry, New York, Basic Books. Quoted from the reprint: London, Fontana Press, 1994.

FERENCZI S., (1922), "Philosophie und Psychoanalyse," Populäre Vorträge über Psychoanalyse, Leipzig-Wien-Zürich, Internationaler Psychoanalytischer Verlag (Erstveröffentlichung Imago, I, 1912).

FISHMAN D., (1999), The Case for a Pragmatic Psychology, New York, New York University Press.

FREUD S., SE, (1953-1966), The Standard Edition of the Complete Psychological Works of Sigmund Freud, ed. by J. Strachey, 24 vols. London, Hogarth Press.

FREUD S., (1892-93), “A Case of Successful Treatment by Hypnotism with Some Remarks on the Origin of Hysterical Symptoms through 'Counter Will'," in SE, vol. 1.

FREUD S., (1905), Jokes and Their Relation to the Unconscious, in SE, vol. 8.

FREUD S., (1910a), “The Future Prospects of Psycho-Analytic Therapy,” in SE, vol. 11.

FREUD S., (1910b), “'Wild' Psycho-Analysis,” in SE, vol. 11.

FREUD S., (1912), “The Dynamics of Transference," in SE, vol. 12.

FREUD S., (1914), “On the History of the Psycho-Analytic Movement," in SE, vol. 14.

FREUD S., (1916), Introductory Lectures on Psycho-Analysis, in SE, vol. 15 and 16.

FREUD S., (1918 [1914]), From the History of an Infantile Neurosis, in SE, vol. 17.

FREUD S., (1925), An Autobiographical Study, in SE, vol. 20.

FREUD S., (1926), “On the Question of Lay Analysis," in SE, vol. 20.

FREUD S., (1930), Civilization and Its Discontents, in SE, vol. 21.

FREUD S., (1932), New Introductory Lectures on Psycho-Analysis, in SE, vol. 22.

FREUD S., (2011), Racconti analitici, introduction by Lavagetto M. (vii-lxvi), Torino, Einaudi.

GOLDBERg A., (2002), “American Pragmatism and American Psycho-analysis," Psychoanalytic Quarterly, 71, 2, 235-50.

Goodman R.B., (2004), Wittgenstein and William James, Cambridge, Cambridge University Press, 1st ed. 2002.

GRÜNBAUM A., (1984), The Foundations of Psychoanalysis: A Philosophical Critique, Berkeley, University of California Press.

HACKING I., (1994), Rewriting the Soul. Multiple Personality and the Sciences of Memory, Princeton, Princeton University Press.

HACKING I., (1998), Mad Travelers: Reflections on the Reality of Transient Mental Illnesses, Charlottesville-London, University of Virginia Press.

HANLY C., (2006), “Pragmatism, Tradition, and Truth in Psychoanalysis," American Imago, 63, 3, 261-82.

ILLES P., (1996), Wahrheitstheorien bei Freud. Von der Korrespondenz zur Art Performance: Eine pragmatisch-ästhetische Untersuchung, Marburg, Tectum. 
JANET P., (1889), L'automatisme psychologique, Paris, Alcan.

JANET P., (1898), Névroses et idées fixes, tomes I-II, Paris, Alcan.

JANET P., (1909), Les névroses, Paris, Flammarion, new edition 1939. Quoted from the digital edition: [dx.doi.org/doi:10.1522/cla.jap.nev].

JANET P., (1923), La médecine psychologique, Paris, Flammarion, new edition Société Pierre Janet, 1980. Quoted from the digital edition: [dx.doi.org/doi:10.1522/cla.jap.med].

JANET P., (1928), L'évolution de la mémoire et de la notion du temps, Compte rendu intégral des conférences faites en 1928 au collège de France, Paris, A. Chahine.

JANET P., (1936), L'intelligence avant le langage, Paris, Flammarion.

KANDEL E.R., (1999), "Biology and the Future of Psychoanalysis: A New Intellectual Framework for Psychiatry Revisited," The American Journal of Psychiatry, 156, 4, 505-24.

LAURENS S. \& T. KOZAKAï,, (2003), “Pierre Janet et la mémoire sociale," Connexions, 2, 80, 59-75.

LEYS R., (1994), “Traumatic Cures: Shell Shock, Janet, and the Question of Memory,” Critical Inquiry , 20, 4, 623-62.

MACINTYRE A., (1958), The Unconscious: A Conceptual Analysis, London, Routledge \& Kegan Paul. Rev. ed. New York, Routledge, 2004.

PINTAR J. \& S.J. LYNN, (2008), Hypnosis: A Brief History, Malden-Oxford-Chichester, Wiley-Blackwell. RENIK O., (2004), “Intersubjectivity in Psychoanalysis," with comments by E. Bott Spillius, International Journal of Psychoanalysis 85, 1053-64.

RICÆUUR P., (1977), “La question de la preuve en psychanalyse," inÉcrits et conférences 1. Autour de la psychanalyse, Paris, Seuil, 2008, 19-71 (originally published as “The Question of Proof in Freud's Psychoanalytic Writings," Journal of the American Psychoanalytic Association 25, 1977).

SCHAFER R., (1976), A New Language for Psychoanalysis, New Haven, Yale University Press.

SCHAFER R., (1995), "In the Wake of Heinz Hartmann," repr. in Id., Tradition and Change in Psychoanalysis, Madison, International Universities Press, 1997.

scull A., (2009), Hysteria: The Biography, Oxford, Oxford University Press.

THORET Y., GIRAUD A. C. \& B. DUCERF, (1999), “La dissociation hystérique dans les textes de Janet et Freud avant 1911," L'évolution psychiatrique 64, 749-64.

WILSON A., (2000), “Commentaries," Journal of the American Psychoanalytic Association 48, 411-7.

ZILBOORG G. in collaboration with HENRY G., (1941), A History of Medical Psychology, New York, W.W. Norton and Co.

\section{NOTES}

1. Except when otherwise specified, "psychoanalysis" and "psychoanalytical" will refer to Freudian psychoanalysis throughout this paper.

2. "[...] experience in its vital form is experimental, an effort to change the given" (Dewey MW 10:

6). For this notion of experimentalism see Dewey 1925 (LW 4: 70).

3. See Brendel (2006: 22). Brendel, however, indicates that whatever little could be offered, so far, in the way of experimental verification pointed to the positive effects of analytical treatment. 
4. Kandel (1999: 505). However, he declares in the same paragraph that "psychoanalysis still represents the most coherent and intellectually satisfying view of the mind."

5. The first reaction can be further subdivided, and I will tackle one of its forms in section 2 . Freud's first model of the mind (his "first topography") included three "systems" (unconscious, preconscious, conscious). For an account of the unconscious as a theoretical construct see MacIntyre 1958.

6. A collection of Freud's best case-narratives (in Italian translation) has been neatly edited by Mario Lavagetto in a recent volume (see Freud 2011). Freud's literary gift was notably acknowledged by the conferral of the Goethe Prize in 1930.

7. Hanly (2006: 276-7) refers to this in terms of a "pragmatic criterion," although it is hard to see what would distinguish it from standard hypothetical-deductive reasoning.

8. Freud himself contributed to the ill fame of American analysis, which he famously deemed as "watered-down" and "superficial" (in his 1925 Selbstdarstellung and elsewhere). Lacan later charged American Ego-psychology of the 1940s-1950s with being subservient to social adaptation; for a reconsideration of Hartmann's Ego-psychology see Schafer 1995. Deleuze and Guattari straightforwardly proclaimed the socially oppressive character of Freudian as well as of any Oedipal-based theory. Other similar charges have been variously raised, and countered by those who insist on the revolutionary nature of psychoanalysis (notably the Argentinian school). Neither critics nor advocates seem to have special inclination towards psychoanalytic pragmatism.

9. I will not consider here revisions of major assumptions of Freudian theory, like the emphasis on object relations over drives.

10. Gadamer and Ricœur (mainly in the Continental tradition), and Wittgenstein (in the AngloAmerican world) have been the main philosophical references for this kind of proposals. I have dwelt at length upon hermeneutic psychoanalysis in Brigati 2001; Brigati 2003, so I will here engage particularly the second trend.

11. Among the most useful accounts see Illes 1996, who reviews a variety of meanings of "truth" to be found in Freud's work, without directly taking sides, but giving a prominent place to pragmatic theory.

12. For a narrative approach based on action-language see Schafer 1976.

13. Ricœur (2008: 22); the word "reports" is in the text, probably coming from the earlier English publication.

14. For pragmatist-minded perspectives on various aspects of psychotherapy, see also Fishman 1999; Goldberg 2002; Hanly 2006; as well as Brendel 2003 and Brendel 2006, who in fact refers to psychiatry at large, but aims precisely at bridging the gap between empirical psychiatry and "humanistic," "insight-oriented" approaches, notably psychoanalytical ones (2006: 24).

15. A few years before, he had been even more explicit: "Pragmatism, as I am using the term in the current context, refers to the theory that psychiatric explanations are 'true' only insofar as they promote beneficial real-world results for individuals with mental illnesses" (Brendel 2003: 568-69, italics added).

16. See The Future of an Illusion for Freud's discussion of Vaihinger.

17. See his famous judgment in Civilization and Its Discontents: "the intention that man should be 'happy' is not included in the plan of 'Creation"' (Freud 1930: 82). This is not to deny that there are deeper, albeit darker, senses of happiness that may be said to be the ultimate stake of treatment, as has been envisaged especially by Melanie Klein.

18. Babini (1990: 54), quoting Janet (1936: 151). Babini shows that it was through Bergson (and the French tradition from Condillac to Maine de Biran) that Janet developed an interest in pragmatism and American social psychology.

19. Janet 1928, quoted in Laurens, Kozakaï 2003, who refer to the reciprocal influence between Janet and Maurice Halbwachs on this point. 
20. Janet's conception of behaviour had quite a complex structure, "une hiérarchie qui comprend les 'actes réflexes' au premier niveau. Ensuite viennent les 'actes perceptifs ou suspensifs,' les 'actes sociaux,' les 'actes intellectuels élémentaires,' les 'actes du plan verbal,' les 'actes asséritifs,' les 'actes réfléchis,' les 'actes rationnels,' les 'actes expérimentaux' et les 'actes progressifs"' (Bühler and Heim 2001: 263). Of course, shifting the focus from behaviour to conduct was a key move of pragmatist psychology (especially Dewey's) as well.

21. This influence, however, was different upon the two: whilst Breuer was willing to acknowledge dissociation in Janet's sense, Freud soon diverged, insisting on the conscious/ unconscious divide and the mechanisms of defence. I am indebted to Nelly Cappelli for pointing this out to me.

22. Thoret et al. (1999: 761) mention an early case in which Freud allegedly did the same thing (Freud 1892-93), but, while it was admittedly a case of suggestion, I cannot find anything like Freud's assuming the role of a character in a play. Anyway, this was not a line he ever later pursued.

23. Both claims are essential part of Janet's theory of memory, as Laurens and Kozakaï point out (2003: 65).

24. See, however, Thoret et al. (1999: 756), who admit that Janet's "psychodrame" might be seen as an "anticipation" of Freudian transference neurosis.

25. To be sure, the surgical metaphor was also invoked by Freud (see the XXVIII Introductory Lesson on Psycho-Analysis, in Freud 1916: vol. 16), but he never avowedly used deception.

26. Zilboorg and Henry (1941: 377).

27. Again and again, one reads descriptions like: "I tried to take away from somnambulic consciousness this fixed and absurd idea that the menstruation was stopped by a cold bath" (Janet 1889: 439, Ellenberger's translation).

28. Leys (1994: 629), based on Janet (1923: 154); on Janet's “cure by telling lies" see also Hacking (1994: 194-7). Hacking stresses how ironic it was that Janet was later to become a hero for the "False Memory" movement, whose members plead for reconsidering the actual truth of early memories of child abuse. As to Freud, though, Hacking sees him as driven by a desire to "get at the Truth by whatever means" (1994: 195). By capitalizing the " $\mathrm{T}$ " he seems to mean a correspondence theory of truth, which is a rather poor reading of Freud's range of meanings for this term (Illes 1996).

29. Zilboorg and Henry (1941: 377). The term normally indicates the resolution of a hypnotic state.

30. See Freud's reconstruction in Freud 1914 and Freud 1925.

31. Of course, there must be a theory of psychic causality that supports this. Therefore, Freud could not help implying that similar result could be brought about by either physical or psychical means. But this need not worry us here.

32. Leaving aside, that is, Ferenczi's challenging utopia of "mutual analysis."

33. Reciprocally, Stanley Cavell has argued, unnecessarily enough, that pragmatism cannot explain the past-oriented phenomenon of mourning. See Colapietro (2004).

34. Colapietro quotes a few passages from Dewey's Human Nature and Conduct to this purpose, yet I find they do not support the claim that Dewey attributed "backward orientation" to psychoanalysis. This is not the place to discuss Dewey's criticisms of psychoanalysis, which are set against a background of the recognition of its merits, and - though sometimes based on misrepresentations - are occasionally anticipatory of matters debated in analytic literature afterwards. I will just mention his talking of "unconscious consciousness" (MW 14: 62), which I take as a warning against regarding unconscious phenomena as mere replicas of conscious ones, relocated in some hidden place.

35. "[...] opponents of the unconscious [...] had never realized the idea that the unconscious is something which we really do not know, but which we are obliged by compelling inferences to 
supply; they had understood it as being something capable of becoming conscious but which was not being thought of at the moment" (Freud 1905: 162). Of course, Ich and Es belong to the language of the "second topic," while "conscious/unconscious" belong to the first, but we need not distinguish between this for present purposes.

36. I am indebted to all of the participants in the 2012-2014 Why Pragmatism? seminars at Villa Vigoni for their comments on the first version of this paper, as well as for the ongoing, invaluable discussion during the whole 3-year project. I wish to thank Valeria Paola Babini, Maria Cecilia Bertolani, Roberto Frega, Federico Zuolo, who read early versions of the text. Nelly Cappelli extensively commented on the paper and provided me with a deeper understanding of the nature of transference and of psychoanalytic matters per se. Daniela Crocetti helped me clarify my language and my thinking.

\section{ABSTRACTS}

Psychoanalysis is sometimes thought to rely on a "pragmatic theory of truth," whose chief assumption should be that the effectiveness of a treatment counts as evidence for the truth of the interpretations provided during each treatment, and/or the psychoanalytic ontology of mind itself. While there is some support for this claim in psychoanalytic views both on the nature of psychic reality and on clinical practice, it needs qualification. It should not be taken to imply that the theory is true because or insofar as it (clinically) works. What I mean to show is, rather, that psychoanalysis is a distinctive illustration of the pragmatist concept that effective explanations are, in Dewey's words, "experimental," and adjust themselves to real processes while changing reality, and indeed by changing reality. Truth enjoys, in psychoanalysis, a peculiar status, being what one might call an emergent property of a relational process. But not just any relational process, even if it "works," will produce truth. The key of psychoanalytic treatment is transference, and the main pragmatic character of transference is what one may call its theatrical quality. I try to clarify this through a comparison of Freud's and Pierre Janet's clinical approaches.

\section{AUTHOR}

\section{ROBERTO BRIGATI}

Alma Mater Studiorum - Università di Bologna, Italy roberto.brigati[at]unibo.it 